\title{
Human mast cells respond to viral infection by recruiting NK cells and T cells
}

\author{
SM Burke ${ }^{1,2^{*}}$, M Shmulevitz ${ }^{2}$ K Mohan ${ }^{1,2,3}$, PWK Lee ${ }^{2}$, TB Issekutz ${ }^{1,2,3,4}$, JS Marshall 1,2,4 \\ From Canadian Society of Allergy and Clinical Immunology Annual Scientific Meeting 2009 \\ Halifax, Canada. 22-25 October 2009
}

In addition to their role in allergic disease, mast cells can respond to many pathogens through the production of proinflammatory mediators. Mast cells are located close to blood vessels and sites of pathogen exposure. $\mathrm{T}$ and NK cells must reach sites of infection to eliminate affected cells, however possible mechanisms mediating this migration are poorly understood. We hypothesized that human mast cells exposed to virus-associated stimuli can recruit $T$ cells and natural killer (NK) cells.

Primary cultures of human cord blood-derived mast cells (CBMC) were activated with poly(I:C), a synthetic analogue of double-stranded RNA (dsRNA), or infected with mammalian reovirus.

CBMC stimulated with poly(I:C) or reovirus produced several chemokines including CCL4 and CXCL8. In vitro chemotaxis assays using human peripheral blood $\mathrm{T}$ cells and NK cells demonstrated a predominant migration of NK cells to poly(I:C)-CBMC supernatants. Reovirus infection of CBMC induced the recruitment of both NK cells and multiple T cell subsets, NK cell recruitment was dependent on CXCL8.

Overall, this is the first study to demonstrate that virus-stimulated mast cells induce the chemotaxis of NK cells and $\mathrm{T}$ cells. These findings may be useful for developing approaches to recruit potent immune effector cells to sites of viral infection, and enhance our understanding of the mechanisms of virus-induced exacerbations of allergic disease.

This work was supported by the Canadian Institutes for Health Research.

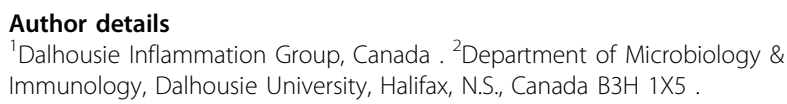

* Correspondence: smburke@dal.ca

${ }^{1}$ Dalhousie Inflammation Group, Canada
${ }^{3}$ Departmenrt of Pathology, Dalhousie University, Halifax, N.S., Canada B3H 1X5 . ${ }^{4}$ Department of Pediatrics, Dalhousie University, Halifax, N.S., Canada B3H $1 \times 5$.

Published: 12 May 2010

doi:10.1186/1710-1492-6-S1-P15

Cite this article as: Burke et al:: Human mast cells respond to viral infection by recruiting NK cells and T cells. Allergy, Asthma \& Clinical Immunology 2010 6(Suppl 1):P15.
Submit your next manuscript to BioMed Central and take full advantage of:

- Convenient online submission

- Thorough peer review

- No space constraints or color figure charges

- Immediate publication on acceptance

- Inclusion in PubMed, CAS, Scopus and Google Scholar

- Research which is freely available for redistribution

Submit your manuscript at www.biomedcentral.com/submit
C Biomed Central 